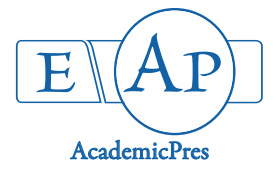

\title{
The Haematology and Serum Biochemistry Profile of Adult Japanese Quail (Coturnix coturnix japonica)
}

\author{
Onyinyechukwu A. AGINA*, Wilfred S. EZEMA, \\ Ezinwa M. IWUOHA
}

University of Nigeria, Faculty of Veterinary Medicine, Department of Veterinary Pathology and Microbiology, Nsukka, Enugu State, Nigeria; onyinye.noel@unn.edu.ng (*orrespondingauthor);wilfred.ezema@unn.edu.ng; ezimadona@gmail.com

\begin{abstract}
The present study established the reference values and sex differences in the erythrocytic and serum biochemistry parameters of domestic adult quails (Coturnix coturnix). Ninety five adult birds, comprising of 42 males and 53 female Japanese quails were sampled using a simple random sampling technique. Standard procedures were carried out in all haematology and serum biochemistry determinations. The overall mean for the erythrocytic and serum biochemistry parameters were as follows: packed cell volume (PCV) $43.11 \%$, red blood cell count (RBC) $4.31 \times 10^{6} / \mu \mathrm{l}$, haemoglobin concentration $(\mathrm{Hbc}) 16.21 \mathrm{~g} / \mathrm{dl}$, mean corpuscular volume (MCV) $100.69 \mathrm{fl}$, mean corpuscular haemoglobin $(\mathrm{MCH}) 39.17$ pg, mean corpuscular haemoglobin concentration (MCHC) $39.35 \mathrm{~g} / \mathrm{dl}$, aspartate aminotransferase (AST) $59.99 \mathrm{IU} / \mathrm{L}$, alanine aminotransferase (ALT) $20.85 \mathrm{IU} / \mathrm{L}$, alkaline phosphatase (ALP) $107.54 \mathrm{IU} / \mathrm{L}$, total proteins (TP) $5.19 \mathrm{~g} / \mathrm{dl}$, albumin (ALB) $3.25 \mathrm{~g} / \mathrm{dl}$, globulin (GLB) $1.94 \mathrm{~g} / \mathrm{dl}$, albumin: globulin 1.73, total cholesterol (TCHOL) $146.69 \mathrm{mg} / \mathrm{dl}$, total bilirubin (TBIL) $2.37 \mathrm{mg} / \mathrm{dl}$, uric acid (UA) $16.02 \mathrm{mg} / \mathrm{dl}$ and creatinine (CREAT) $0.44 \mathrm{mg} / \mathrm{dl}$. The PCV of the males were significantly higher than that of the females, while the $\mathrm{MCH}$ and $\mathrm{MCHC}$ of the females were significantly higher than those of the males. The serum total proteins, albumin, globulin, uric acid, creatinine, and total cholesterol values of the female quails were higher than those of the male quails. The present data might be useful to avian specialists and veterinary clinicians, but more research works should be carried out on quails to increase the information data base, especially in the tropics.
\end{abstract}

Keywords: erythrocytic, serum biochemistry, adult quails, Coturnix coturnix japonica

\section{Introduction}

Quail is a collective name for several genera of mid-sized birds generally considered in the order Galliformes. Old world quail are found in the family Phasianidae and new world quail are found in the family Odontophoridae (Cox et al., 2007). The collective noun for a group of quail is a covey or bevy. The Japanese (Coturnix japonica) and the American quail (Coturnix coturnix) are the two main kinds of quails suitable for breeding. Japanese quails are from pheasant family and are migratory birds and migrate between Asia and Europe.

Young Coturnix coturnix japonica is yellowish in appearance with stripes of brown and somewhat resemble turkey poults except for size. The newly hatched quails weigh between 6-8 grams (Hall, 2012) but grow rapidly during the first few days and are fully feathered at about 4 weeks of age. The adult male quail weighs between 100-130 grams (Mizutani, 2003). The male birds can be identified readily by the rusty dark brown colour of the breast feather. Males also have a cloacal gland, a bulbous structure located at the upper edge of the vent which secretes a white foamy material. This unique material can be used to access the reproductive fitness of the males. The young male begins to crow at 5-6 weeks old. The adult female quail is slightly heavier than the male weighing from 120-160 grams (Ortlieb, 2013). The body colouration of the female bird is similar to the male except that the feathers on the throat and upper breast are long, pointed and much lighter cinnamon. The light tan breast feathers are characteristically black-stripped. In order to produce fertile eggs, males and females should be enclosed with a maximum of two females per male (Ranklin et al., 1998).

The relevance of protein in human and animal nutrition cannot be over emphasized. Recently, there has been a significant short fall between the production and supply of animal protein to feed the increasing population. For example, Nigeria is highly deficient in animal protein security with the per capita consumption put at $9.3 \mathrm{~g} /$ day as against the $34 \mathrm{~g} /$ day recommended by the FAO to be the minimum requirement for the growth and development of the body (Esobhawan et al., 
68

2008). To arrest this trend, efforts have been directed towards boosting the animal industry with micro-livestock having prolific tendency, short gestation period, short generation interval and rapid growth. Among the micro-livestock animals, the Japanese quail should be the choice in increasing animal protein base in the developing countries.

Although, emphasis has been on domestic fowl production, nutritive and economic benefits can be derived from quail production since the quail is fast growing and resistant to many diseases than domestic fowls (Oluyemi and Roberts, 2000). Japanese quails are hardy birds that thrive in small cages and are inexpensive to produce. They require less floor space; about 810 adult quails can be reared in a space meant for one adult chicken (Haruna et al., 1997). They have less feed requirement and an adult quail requires only 20-25 g feed per day compared to chicken (120-130g) per day (Ani et al., 2009). Other unique characteristics and advantages of quails over other species of poultry include early attainment of sexual maturity, being able to come to lay as early as 5-6 weeks of age, having short generation interval making it possible to have many generations in a year (Robbins, 1981; Annon, 1991), attaining market weight of 150-180 g between 5-6 weeks of age and a high rate of egg production between 180-250 (Garwood and Diehl, 1987) and 200-300 eggs in their first year of lay (NRC, 1991). Reports by Haruna et al. (1997) and Olubamiwa et al. (1999) showed that quail meat and eggs are renowned for their high quality protein, high biological value and low caloric content, making it a choice product for hypertension prone individuals. According to Babangida and Ubosi (2005), the Japanese quail has the potential to serve as an excellent and affordable source of animal protein.

Evaluation of the haematological and serum biochemistry profile of quails provide useful information about their physical condition, making them useful tools in differentiating apparently healthy birds from abnormal or diseased ones. Although, the Japanese quail is fairly resistant to diseases, serum biochemistry data can still be useful in disease diagnosis and monitoring responses in quails, which often show no clinical signs (Fudge, 1997). Also, determination of haematological parameters in quails helps in the clinical management of disorders of the blood and bone marrow. Factors that may affect haematological parameters include subclinical infections, age, species, sex, breed, nutritional status, method of analysis and duration of storage of samples, haemostatic disorders such as bacterial and viral infections, and vitamin $\mathrm{K}$ deficiency (Sparling et al., 1999).

\section{Materials and Methods}

\section{Study area}

The study was carried out within Nsukka metropolis, Enugu state, Nigeria. Nsukka is a sub-urban town situated within the derived savannah belt of Eastern Nigeria between latitudes $5^{\circ} 50$ and $7^{\circ} 00 \mathrm{~N}$ and longitudes $6^{\circ} 52$ and $7^{\circ} 54 \mathrm{E}$, at an average elevation of approximately $500 \mathrm{~m}$ above sea level (FMANR, 2005). It is an area of high temperature with a yearly minimum and maximum temperature of $24.28^{\circ} \mathrm{C}$ and $32.19^{\circ} \mathrm{C}$, with a mean of $28.24^{\circ} \mathrm{C}$, and a relative humidity of about $70 \%$ during the rainy season and about $20 \%$ during the dry season (FMANR 2005).

\section{Studypopulation}

The Japanese quails raised by poultry farmers resident within Nsukka metropolis, between the months of JanuaryApril 2014, represented the studied population. The quails were selected by a simple random sampling method and a total of ninety-five quails were sampled. The sex of each bird was determined before blood collection history of the quails was also obtained from questionnaires administered to the farmers.

\section{Blood sample collection}

Three millilitres of blood was collected from the right jugular vein using a 23 gauge needle attached to a $5 \mathrm{ml}$ syringe. One $\mathrm{ml}$ of the blood sample was delivered into sample bottles containing EDTA $(1 \mathrm{mg} / \mathrm{ml})$ for haematological determinations. The sample bottles were gently shaken to mix up the blood with EDTA to prevent clotting and properly labelled. The remaining $2 \mathrm{ml}$ of blood was emptied into test tubes without anticoagulant and was used for serum biochemistry determinations The serum was obtained by allowing the blood sample to clot at room temperature for one hour after which it was centrifuged for 10 minutes at $3000 \mathrm{~g}$ using a clinical table centrifuge (Ajmer, India), to facilitate complete separation of the serum from clotted blood. The serum was then carefully aspirated with a syringe and needle and deposited into clean serum sample bottles.

\section{Haematological and serum biochemistry procedures}

The erythrocytic and serum biochemistry determinations were carried out following standard procedures. The packed cell volume (PCV) was determined by the micro-haematocrit method (Thrall and Weiser, 2002), haemoglobin concentration $(\mathrm{Hbc})$ was determined by the cyanomethemoglobin method (Higgins et al., 2008). Red blood cell (RBC) count was carried out by haemocytometer method (Thrall and Weiser, 2002). The mean corpuscular values - mean corpuscular volume (MCV), mean corpuscular haemoglobin $(\mathrm{MCH})$, and mean corpuscular haemoglobin concentration (MCHC) was calculated using the standard formulae (Coles, 1986).

The serum biochemistry determinations were carried out using commercial test kits, Quimica Clinica Aplicada (QCA) test kits (QCA, Spain), Randox tests kits (Randox, UK) for total proteins and albumin, and a digital colorimeter (Lab-tech, India). The serum alanine aminotransferase (ALT) and aspartate aminotransferase (AST) activities were determined by the Reitman-Frankel method (Reitman and Frankel, 1957). The serum alkaline phosphatase (ALP) activity was determined by the phenolphthalein monophosphate method (Babson et al., 1966) while the total serum proteins were determined by the direct Biuret method (Lubran, 1978) and the serum albumin was determined by the Bromocresol green method (Doumas et al, 1971). The serum globulin was calculated as the difference between the serum total proteins and serum albumin (Colville, 2002) while the serum total bilirubin was determined by the Jendrassik-Grof method (Doumas et al., 1973). The uric acid was determined by the Uricase-Peroxidase method (Trinder, 1969), while the serum creatinine was determined by the modified Jaffe method (Blass et al., 1974). The serum cholesterol was determined by the enzymatic colorimetric method (Allain et al., 1974). 


\section{Ethics}

The quails were handled humanely in accordance with the Ethics and Regulation Guiding the Use of Research Animals as approved by the Faculty of Veterinary Medicine, University of Nigeria, Nsukka.

\section{Statistical analysis}

Data generated from the study was subjected to descriptive statistics using SPSS 16.0. The differences between the haematological and serum biochemistry parameters of the male and female quails were analysed using students $t$ test. The data were presented as means and standard error of means, and the range of values for each parameter. Significant difference was accepted at the probability level, $\mathrm{p}<0.05$.

\section{Results}

\section{Erythrocytic profile}

The overall mean values for the erythrocytic parameters of the Japanese quail, with the minimum and maximum values in parenthesis were as follows: packed cell volume (PCV) 43.11 [25.00 - 66.00], red blood cell count (RBC) $4.31 \times 10^{6} / \mu l$ [2.02 - 6.99], haemoglobin concentration (Hbc) $16.21 \mathrm{~g} / \mathrm{dl}$ [8.61 - 20.57], mean corpuscular volume (MCV) $100.69 \mathrm{fl}$ [64.68 - 131.91], mean corpuscular haemoglobin $(\mathrm{MCH})$ 39.17 pg [20.72 - 69.08], mean corpuscular haemoglobin concentration (MCHC) $39.35 \mathrm{~g} / \mathrm{dl}[20.77$ - 64.28] (Table 1).

\section{Serum biochemistry profile}

The overall mean values for the serum biochemistry parameters of the Japanese quail, with the minimum and maximum values in parenthesis were as follows: aspartate aminotransferase (AST) 59.99 IU/L [23.85 - 90.70], alanine aminotransferase (ALT) 20.85 IU/L [10.17 - 38.51], alkaline phosphatase (ALP) 107.54 IU/L [86.21 - 113.29], total proteins (TP) $5.19 \mathrm{~g} / \mathrm{dl}[2.75$ - 7.84], albumin (ALB) 3.25 $\mathrm{g} / \mathrm{dl}[1.08$ - 5.47], globulin (GLB) $1.94 \mathrm{~g} / \mathrm{dl}$ [1.00 - 3.11], albumin: globulin $(\mathrm{A} / \mathrm{G}) 1.73[0.43-3.81]$, total cholesterol (TCHOL) $146.69 \mathrm{mg} / \mathrm{dl}[33.33$ - 266.67], total bilirubin (TBIL) $2.37 \mathrm{mg} / \mathrm{dl}$ [0.89 - 4.32], uric acid (UA) $16.02 \mathrm{mg} / \mathrm{dl}$ $[1.27-29.27]$ and creatinine (CREAT) $0.44 \mathrm{mg} / \mathrm{dl}[0.15-$ $0.92]$ (Table 2)

\section{Sex differences in the erythrocytic and serum biochemistry parameters}

There was a significant difference in the PCV of the males and female adult quails, with the PCV of the males significantly higher $(51.74 \%)$ than those of the females $(36.26 \%)$ (Table 3$)$. There was no significant sex difference between the Hbc of the male (16.96) and the female (15.62) quails (Table 3). There was no difference between the RBC count of the male (5.00 $\left.10^{6} / \mu \mathrm{l}\right)$ and the female $\left(3.76 \times 10^{6} / \mu \mathrm{l}\right)$ quails (Table 3), but the $\mathrm{RBC}$ count of the males was higher than the females. No significant difference was observed between the MCV of the males $(103.58 \mathrm{fl})$ and that of the female $(97.62 \mathrm{fl})$ quails, but MCV of the males was higher than that of the females. There was a difference between the $\mathrm{MCH}$ of the males $(35.27 \mathrm{pg}$ ) and that of the females (42.26 pg) (Table 3), with the MCH of the female quails significantly higher than that recorded for the male quails. Also a difference was observed between the MCHC of the males (34.03) and that of the females (43.56) (Table 3), with the MCHC of the female quails significantly higher than those of the male quails.

The AST value of the male quails was higher, though not significant to the AST value of the female quails, thus, no significant difference was observed between the AST value of the males $(61.90 \mathrm{IU} / \mathrm{L})$ and those of the female $(58.47 \mathrm{IU} / \mathrm{L})$ (Table 4).

No significant difference was observed between the ALT value of the males and that of the female quails (Table 4). There was no significant difference observed between the ALP value of the males (106.3 IU/L) and that of the females (109 IU/L). There was a notable difference between the TP value of the males and that of the females (Table 4), with the total protein of the female quails significantly higher than that recorded for the male quails. In addition there was a significant sex difference between the albumin value of the males $(1.64 \mathrm{~g} / \mathrm{dl})$ and those of the females $(4.53 \mathrm{~g} / \mathrm{dl})$ (Table 4$)$, with the albumin value of the female quails higher than that recorded for the male quail. There was a difference between the globulin of the males $(1.76 \mathrm{~g} / \mathrm{dl})$ and that of the females $(2.06 \mathrm{~g} / \mathrm{dl})$ (Table 4$)$, with the globulin of the female quails significantly higher than that recorded for the male quails. Regarding the $\mathrm{A} / \mathrm{G}$ ratio of the males (1.00) there was a difference between it and those of the female quails (2.32), with the $A / G$ of the female quails significantly higher than that recorded for the male quails. There was a significant difference between the total cholesterol value of the males $(78.57 \mathrm{mg} / \mathrm{dl})$ and that of the females $(200.67 \mathrm{mg} / \mathrm{dl}$ ) (Table 4), with the total cholesterol value of the female quails higher than that of the male quails. Between the total bilirubin of the males and that of the females (Table 4), there was a significant difference with the total bilirubin value of the female quails significantly higher than that of the male quails. There was a difference between the uric acid value of the males $(5.66 \mathrm{mg} / \mathrm{dl})$ and that of the females $(24.23 \mathrm{mg} / \mathrm{dl})$, with the uric acid level of the female quails higher than that of the male quails. No significant difference was observed between the creatinine level of the male $(0.44$ $\mathrm{mg} / \mathrm{dl})$ and those of the female quails $(0.43 \mathrm{mg} / \mathrm{dl})$ (Table 4$)$.

Table 1. The erythrocytic profile of adult Japanese quail (Coturnix coturnix japonica)

\begin{tabular}{|c|c|c|}
\hline Parameters & $\begin{array}{c}\text { Overall mean } \pm \text { SE } \\
(n=95)\end{array}$ & Minimum and maximum values \\
\hline Packed Cell Volume (\%) & $43.11 \pm 1.08$ & $25.00-66.00$ \\
\hline Red Blood Cell $\left(\times 10^{6} / \mu \mathrm{l}\right)$ & $4.31 \pm 0.11$ & $2.02-6.99$ \\
\hline $\begin{array}{c}\text { Haemoglobin } \\
\text { Concentration }(\mathrm{g} / \mathrm{dl})\end{array}$ & $16.21 \pm 0.27$ & $8.61-20.57$ \\
\hline $\begin{array}{c}\text { Mean Corpuscular } \\
\text { Volume (fl) }\end{array}$ & $100.69 \pm 1.38$ & $64.68-131.91$ \\
\hline $\begin{array}{l}\text { Mean Corpuscular } \\
\text { Haemoglobin }(p g)\end{array}$ & $39.17 \pm 0.93$ & $20.72-69.08$ \\
\hline $\begin{array}{c}\text { Mean Corpuscular Haemoglobin } \\
\text { Concentration }(\mathrm{g} / \mathrm{dl})\end{array}$ & $39.35 \pm 0.97$ & $20.77-64.28$ \\
\hline
\end{tabular}


Table 2. The serum biochemistry profile of adult Japanese quail (Coturnix coturnix japonica)

\begin{tabular}{ccc}
\hline Parameters & $\begin{array}{c}\text { Overall mean } \pm \text { SEM } \\
(\mathrm{n}=95)\end{array}$ & Minimum and maximum values \\
\hline Aspartate aminotransferase $(\mathrm{IU} / \mathrm{L})$ & $59.99 \pm 1.42$ & $23.85-90.70$ \\
Alanine aminotransferase $(\mathrm{IU} / \mathrm{L})$ & $20.85 \pm 0.89$ & $10.17-38.51$ \\
Alkaline phosphatase $(\mathrm{IU} / \mathrm{L})$ & $107.54 \pm 0.68$ & $86.21-113.29$ \\
Total protein $(\mathrm{g} / \mathrm{dl})$ & $5.19 \pm 0.17$ & $2.75-7.84$ \\
Albumin $(\mathrm{g} / \mathrm{dl})$ & $3.25 \pm 0.15$ & $1.08-5.47$ \\
Globulin $(\mathrm{g} / \mathrm{dl})$ & $1.94 \pm 0.04$ & $1.00-3.11$ \\
A/G & $1.73 \pm 0.09$ & $0.43-3.81$ \\
Total cholesterol $\mathrm{mg} / \mathrm{dl})$ & $146.69 \pm 7.21$ & $33.33-266.67$ \\
Total bilirubin $(\mathrm{mg} / \mathrm{dl})$ & $2.37 \pm 0.07$ & $0.89-4.32$ \\
Uric acid $(\mathrm{mg} / \mathrm{dl})$ & $16.02 \pm 1.01$ & $1.27-29.27$ \\
Creatinine $(\mathrm{mg} / \mathrm{dl})$ & $0.44 \pm 0.22$ & $0.15-0.92$ \\
\hline
\end{tabular}

Table 3. Comparison of the erythrocytic profile of the male and female adult Japanese quail (Coturnix coturnix japonica)

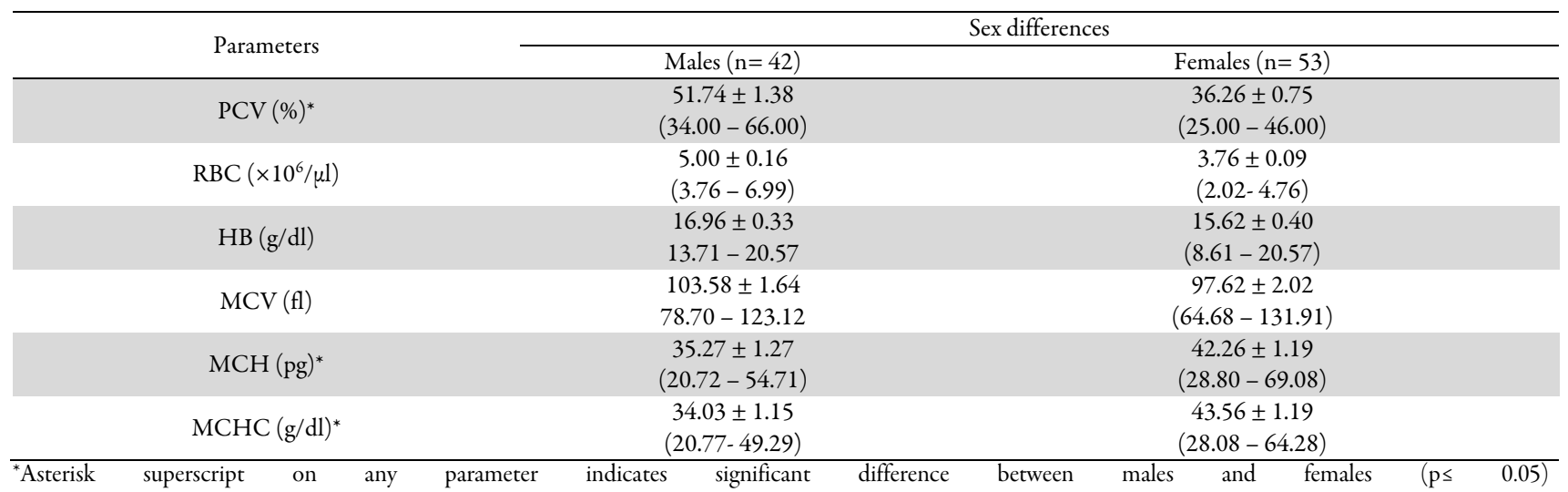

Table 4. Comparison of serum biochemistry profile of male and female adult Japanese quail (Courtinix courtinix japonica)

\begin{tabular}{|c|c|c|}
\hline \multirow{2}{*}{ Parameters } & \multicolumn{2}{|c|}{ Sex Differences } \\
\hline & Males $(n=42)$ & Females $(n=53)$ \\
\hline Aspartate aminotransferase (IU/L) & $\begin{array}{c}61.90 \pm 1.97 \\
(30.70-90.70)\end{array}$ & $\begin{array}{c}58.47 \pm 1.99 \\
(23.85-85.00)\end{array}$ \\
\hline Alanine aminotransferase (IU/L) & $\begin{array}{c}23.20 \pm 1.34 \\
(10.17-38.50)\end{array}$ & $\begin{array}{c}18.99 \pm 1.13 \\
(10.17-38.50)\end{array}$ \\
\hline Alkaline phosphatase (IU/L) & $\begin{array}{c}106.30 \pm 1.29 \\
(86.21-113.29)\end{array}$ & $\begin{array}{c}109 \pm 0.64 \\
(86.21-113.29)\end{array}$ \\
\hline Total protein $(\mathrm{g} / \mathrm{dl})^{*}$ & $\begin{array}{c}3.42 \pm 0.05 \\
(2.75-3.95)\end{array}$ & $\begin{array}{c}6.59 \pm 0.39 \\
(5.67-7.84)\end{array}$ \\
\hline $\operatorname{Albumin}(\mathrm{g} / \mathrm{dl})^{*}$ & $\begin{array}{c}1.64 \pm 0.06 \\
(1.08-2.80)\end{array}$ & $\begin{array}{c}4.53 \pm 0.05 \\
(3.94-5.47)\end{array}$ \\
\hline Globulin $(\mathrm{g} / \mathrm{dl})^{*}$ & $\begin{array}{c}1.78 \pm 0.06 \\
(1.00-2.63)\end{array}$ & $\begin{array}{l}2.06 \pm 0.05 \\
(1.31-3.11)\end{array}$ \\
\hline A/G ratio* & $\begin{array}{c}1.00 \pm 0.07 \\
(0.43-2.51)\end{array}$ & $\begin{array}{c}2.32 \pm 0.08 \\
(1.35-3.81)\end{array}$ \\
\hline Total cholesterol $(\mathrm{mg} / \mathrm{dl})^{*}$ & $\begin{array}{c}78.57 \pm 2.95 \\
(33.33-118.00)\end{array}$ & $\begin{array}{c}200.67 \pm 6.00 \\
(0.86-4.32)\end{array}$ \\
\hline Total bilirubin (mg/dl) & $\begin{array}{c}2.30 \pm 0.08 \\
(0.86-3.46)\end{array}$ & $\begin{array}{c}2.43 \pm 0.11 \\
(0.86-4.32)\end{array}$ \\
\hline Uric acid $(\mathrm{mg} / \mathrm{dl})^{*}$ & $\begin{array}{c}5.66 \pm 0.41 \\
(1.27-10.54)\end{array}$ & $\begin{array}{c}24.23 \pm 0.50 \\
(7.64-29.27)\end{array}$ \\
\hline Creatinine $(\mathrm{mg} / \mathrm{dl})$ & $\begin{array}{c}0.44 \pm 0.03 \\
(0.15-0.92)\end{array}$ & $\begin{array}{c}0.43 \pm 0.03 \\
(0.15-0.92)\end{array}$ \\
\hline
\end{tabular}

\section{Discussion}

When the results of this study were compared with reference values of Ayub et al. (2012), increases in the PCV, $\mathrm{RBC}$ and $\mathrm{Hb}$ values were observed. These increases, could be attributed to environmental variations. The high PCV of the males, and the high $\mathrm{MCH}$ and $\mathrm{MCHC}$ of the females are in agreement with Addass et al. (2012), who reported that sex have a significant effect on haematological parameters, with males having higher PCV value and females having higher $\mathrm{MCHC}$ and $\mathrm{MCH}$ values. The high $\mathrm{PCV}$ without a concurrent significant increase in RBC count in males as observed in this study is not clearly understood, but may be attributed to error in manual counting of red blood cells.

The serum biochemistry parameters obtained in this study differed from those of Scholtz et al. (2009) who found 
considerably higher results, while the total proteins, globulin, albumin, uric acid and creatinine levels are similar to those obtained by Prakash (2013). Sex related differences were observed in females having higher albumin, globulin, total protein, uric acid and total cholesterol concentrations than males. These differences could be explained by the physiological changes in the female quail due to egg laying (Walzem et al., 1999). During the laying period, hepatic synthesis of triglycerides, phospholipids and cholesterol is increased. These lipids make up the lipoproteins, which are circulated in the blood and incorporated into the oocytes of the ovaries. Thus, laying birds have higher circulating concentrations of triglycerides and cholesterol in contrast to male birds. In addition, females of oviparous species demonstrate a marked increase in total protein concentration during egg production (Coenen et al., 1994). This is as a result of increased secretion of oestrogen which causes an increase in production of egg yolk precursor's vitellogenin and lipoproteins (Lumeij, 1997), thus leading to an increase in the total protein concentration in blood and serum of these birds. The elevated concentration of total protein in egg-laying birds is accompanied by significant increases in levels of serum albumin and globulin (Hunt and Hunsaker, 1995). The significant increase in serum uric acid in females than males maybe attributed to ovulatory activity of female birds. This is also observed in domestic turkeys (Agina et al., 2015) and domestic chicken (Ibrahim et.al, 2012).

\section{Conclusions}

The present study noted a high PCV and RBC values for the males, and significantly higher total proteins, albumin, globulin, albumin: globulin ratio, total cholesterol and uric acid concentrations were obtained for the females. This data may be useful to avian specialists and veterinary clinicians.

\section{References}

Agina OA, Ezema WS, Nwishienyi CN (2015). Haemato-biochemical profile of apparently healthy domestic turkey (Meleagris gallopavo) in Nsukka, Enugu State Nigeria. Animal Research International 12(1):2120-2129.

Addass PA, David DI, Edward A, Zira KE, Midak A (2012). Effect of age, sex and management system on some haematological parameters of intensively and semi-intensively kept chicken in Mubi. Iranian Journal of Applied Animal Science 2(3):277-282.

Allain CC, Poon LS, Chan CS, Richmond W, Fu PU (1974). Enzymatic determination of total cholesterol. Clinical Chemistry 20:470-475.

Ani AO, Okeke GC, Emeh MB (2009). Response of growing Japanese quail (Coturnix coturnix japonica) chicks to diets containing different energy and protein levels. Proceedings of the $34^{\text {th }}$ Annual Conference Nigeria Society for Animal Production, 15th - 18th March, Uyo, pp. 328-331

Annon L (1991). Little known animals with promising economic future (micro-livestock). Board of Science and Technology for International Development, National Academy Press, Washington DC pp 147-155.

Ayub A, Hmar L, Prava M, Lallianchhunga MC, Tolenkhomba TC (2012). Effect of age on the haematological and biochemical profile of Japanese quails (Coturnix coturnix japonica). International
Multidisciplinary Research Journal 2(8):32-35.

BabangidaS, Ubosi CO (2005). Effects of varying dietary protein levels in the performance of laying Japanese quail (Coturnix coturnix japonica) in a semi-arid environment. Nigerian Journal of Animal Production 33(1):45-52.

Babson AL, Greeley SJ, Coleman CM, Philips GE (1966). Phenolphthalein monophosphate as a substrate for serum alkaline phosphatase. Clinical Chemistry 12:482-490.

Blass KG, Thiebert RJ, Lam LK (1974). A study of the mechanism of the Jaffe reaction. Journal ofClinical Biochemistry 12:336-343.

Coenen TMM, Enninga IC, Cave DA, van der Hoeven JCM (1994). Hematology and serum biochemistry of Japanese quail fed dietary tri-nbutyltin oxide during reproduction. Archives of Environmental Contamination and Toxicology 26:227-233.

Coles EH (1986). Veterinary Clinical Pathology $4^{\text {th }}$ Edition. W.B. Saunders, Philadelphia.

Colville J (2002). Blood chemistry. In: Hendrix CM (Ed). Laboratory Procedures for Veterinary Technicians. $4^{\text {th }}$ Ed. Mosby, St. Louis, pp 75103.

Cox WA, Kimball RT, Braun EL (2007). Phylogenetic position of the new World Quail (Odontophoridae): Eight nuclear Loci and three Mitochondrial Regions contradict morphology and the Sibley Ahlquist tapestry. The Auk 124(1):71-84.

Doumas BT, Perry BW, Sasse EA, Straumfjord JV (1973). Standardization in bilirubin assays: Evaluation of selection methods and stability of bilirubin solutions. Clinical Chemistry 19:984993.

Doumas BT, Watson WA, Biggs HG (1971). Albumin standards and the measurement of serum albumin with bromocresol green. Clinical ChimicaActa 31:87-96.

Esobhawan AO, Ojo SO, Ikhelao EE (2008). Profitability, input elasticity and returns to scale in agriculture production in Lagos State. Proceedings of the $14^{\text {th }}$ Annual Conference of Agriculture in Nigeria Wetlands FUTAAkurepp 219-222.

Federal Ministry of Agriculture and Natural Resources (FMNAR) (2005). Geographical Data, FMNAREnugu, Nigeriapp 17-18.

Fudge AM (1997). Avian Clinical Pathology, Haematology and Chemistry. In: Altman RB, Clubb SL, Dorrestein GM, Quesberry K (Eds). Avian Medicine and Surgery. WBSaunders Co, Philadelphia pp 142-157.

Garwood AA, Diehl RCJ (1987). Body volume and density of live Cortunix quail and associated genetic relationship. Poultry Science 66(8):1269.

Hall G (2012). Brown quail and its management. 2012-05-brown-quailand-its-management.pdf.

Haruna ES, Musa U, Lombin LH, Tat PB, Shamaki D, Okewole P, Molokwu JU (1997). Introduction of quail production in Nigeria. Nigerian Veterinary Journal 18:104107.

Higgins T, Beutler E, Doumas BT (2008). Measurement of Hemoglobin in Blood In: Burtis CA, Ashwood ER, Bruns DE (Eds). Tietz Fundamentals of Clinical Chemistry, $6^{\text {th }}$ Edition. Saunders Elsevier, Missouripp 514515.

Hunt JR, Hunsaker WG (1965). Physiology of the growing and adult goose. 3. Nitrogen constituents of blood. British Poultry Science 6:15-21.

Ibrahim AA, Aliyu J, Abdu MI, Hassan AM (2012). Effects of age and sex 
72

on serum biochemistry values of turkeys (Meleagris gallopavo) reared in the semi-arid environment of Nigeria. World Applied Science Journal 16(3):433-436.

Lubran MM (1978). The measurement of total serum proteins by the Biuret method. Annals of Clinical Laboratory Science 8:106-110.

Lumeij JT (1997). Avian Clinical Biochemistry. In: Kaneko KK, Harvey JW, Bruss ML (Eds). Clinical Biochemistry of Domestic Animals. Academic Press, San Diego, CA pp 857883.

Mizutani M (2003). The Japanese Quail. Retrieved 2014 June 12 from www.angrin.tlrigov.tw/apec 2003/chapter/pdf.

National Research Council (NRC) (1991). Quail. In: Micro livestock - little known small animals with a promising future. National Academy Press, Washington DCpp 147-155.

Olubamiwa O, Haruna ES, Musa U, Akinwole TO, Combin LH, Longe GO (1999). Effects of different energy levels of cocoa based diets on the productive performance of Japanese quail. Nigerian Journal of Animal Production 26:88-92.

Oluyemi JA, Roberts FA (2000). Poultry production in the warm climate. Macmillan Publishers, Limited, London pp 18-34

Ortlieb AG (2013). Raising Coturnix Quail. www.howtoraisequail.com/ coturnix quail.

Prakash RK (2013). Serum Biochemical Profile of Japanese Quails (Coturnix coturnix japonica). Indian Journal of Fundamental and AppliedLife Sciences 3(1):182-183.
Ranklin FW, Artin A, Lison GM, Artin D, Nnabelle MA (1998). Quail: An egg and meat production system. www.echocommunity. org/quailegg.pdfAccessed $16^{\text {th }}$ May 2014.

Reitman S, Frankel S (1957). A colorimetric method for determination of serum glutamic oxaloacetic and glutamic pyruvic transaminase. American Journal ofClinical Pathology 28:56-62.

Robbins GES (1981). Quails, their breeding and management. Publisher World Pheasant Association(WPA),pp 9:10.

Scholtz N, Halle I, Flachowsky G, Sauerwein H (2009). Serum chemistry reference values in adult Japanese quail (Coturnix coturnix japonica) including sex-related differences. PoultryScience 88:1186-1190.

Sparling DW, Dag D, Klein P (1999). Acute toxicity and sublethal effects of white phosphorous in mute swans, Cygnus olor. Archives of Environmental Contamination and Toxicology 36:316-322.

Thrall MA, Weiser MG (2002). Haematology. In: Hendrix CM (Ed). Laboratory Procedures for Veterinary Technicians, $4^{\text {th }}$ Edition. Mosby Inc, Missouripp 29-74.

Trinder P (1969). Uricase-POD method. Annals of Clinical Biochemistry 6:24-27.

Walzem R, Hansen LRJ, Williams DL, Hamilton RL (1999). Estrogen induction of VLDLy assembly in egg-laying hens. Journal of Nutrition 129:467S-472S. 